\title{
Lexical Errors Found in Subtitling Projects of EFL Learners of University of Lancang Kuning
}

\author{
Destina Kasriyati $^{1]}$, Siti Rafiah ${ }^{2]}$, Herdi ${ }^{3]}$, M. Fadhly Farhy Abbas ${ }^{4]}$ \\ Universitas Lancang Kuning \\ E-mail: ${ }^{1]}$ destina@unilak.ac.id \\ ${ }^{2]}$ srafiah297@gmail.com \\ 3]herdi@unilak.ac.id \\ ${ }^{4]}$ fadhly@unilak.ac.id
}

\begin{abstract}
The phenomenon of the study is some students wrongly order the word in a sentence as the result of word by word translation and they translate it using translation machine like Google translate so that it is still has an errors in sentence or word. By doing the project uploaded as subtitle in form of video and music in students' You Tube channel, so around the world see it and become evaluation to the next translator become a good translator. The research aimed to find out the common lexical errors in subtitling projects at the eighth semester students of English Education Department. The research design was descriptive quantitative. Subject the research was 20 students. The instrument was documentation. From the data analysis by rater's one, it was found that students made lexical error was 136 cases included in semantic confusion was 44 cases with percentages $32.35 \%$ was the common lexical error. From the rater's two was 109 lexical errors still with semantic confusion was 40 cases with percentage $36.69 \%$. It means that the students had enough English vocabulary but they do not know the usage of words in sentences when translate it. Also, it means that students need more practice in translation because of some errors still happen.
\end{abstract}

Keywords: Error, Lexical Errors, Translation.

\section{Lexical Error yang ditemukan pada Tugas Subtitling Mahasiswa EFL di Universitas Lancang Kuning}

\begin{abstract}
Abstrak
Fenomena dari studi ini ialah beberapa mahasiswa salah dalam menempatkan kata di kalimat yang hasil dari terjemahan kata per kata dan mereka menterjemahkannya melalui mesin penerjemah seperti Google terjemahan jadi masih terdapat kesalahan di kalimat ataupun di kata. Karena proyek ini dalam bentuk subtitle video atau musik, dan di upload ke channel YouTube masing-masing mahasiswa, jadi seluruh dunia melihat dan menjadi evaluasi bagi generasi penerjemah selanjutnya menjadi penerjemah yang lebih baik lagi. Penelitian ini bertujuan untuk menemukan kesalahan leksikal yang sering terjadi pada proyek pembuatan subtitle pada mahasiswa semester delapan di Prodi Pendidikan Bahasa Inggris Universitas Lancang Kuning. Menggunakan desain deskriptif quantitative. Sampel yang digunakan adalah 20 mahasiswa. Instrumennya adalah dokumentasi. Dari data yang dianalisis oleh rater pertama, ditemukan bahwa
\end{abstract}


ada 136 kesalahan termasuk, semantic confusion berjumlah 44 kasus dengan persentase $32.35 \%$ yang merupakan kesalahan leksikal terbanyak. Begitu juga yang ditemukan oleh rater kedua yakni terdapat 109 kesalahan yang mana juga terdapat 40 kasus semantic confusion dengan persentase 36.69\%. Hal ini terjadi karena mahasiswa cukup kosa kata bahasa Inggris tetapi mereka tidak tahu cara menggunakannya ketika menterjemahkannya. Ini menunjukkan bahwa mahasiswa membutuhkan banyak latihan menterjemahkan karena masih banyak ditemukannya kesalahan.

Kata kunci: Kesalahan, Kesalahan Leksikal, Penerjemahan.

\section{INTRODUCTION}

Nowadays, people cannot separate from what it is called language. Language has an important role in human life. Language used in communication tool between human beings. Language is used in communication each other. It has an important role to convey messages, ideas or information. Sometimes, the information consists of just being published or need to translate. Translation is taking a big part in communicating source language to the target language, as the speaker tells what they want, and convince the receiver to understanding what the speaker says. Translating is different with speaking, when speaking loss some gramaticals, it did not loss meaning, the listener kept understanding that the speakers said, while translation provided well gramatical and there was not miss spelling.

Translation is very important that the world is becoming increasingly narrow and people need to exchange information and work together with people from different countries. Rather than merely transferring one form of words into another, the translator has the capacity to enhance our understanding of development issues and indigenous culture by mediating ideas across cultural and national and boundaries.

By translation, people can take many advantages given in terms of science; people can get latest information to the development of science since it is translated into language of certain countries. The advantage of the translation in term of trade was to ease transaction. For that reason, reliable translator is needed, in this case the students, especially those who majored in English, are expected to have skills to translate well.

During translate one language to other languages; of course some mistakes or errors can be happen. Language transfer (also known as L1 interference, linguistic interference, and cross meaning) refers to speakers or writers applying knowledge from their native language to a second language. It is most commonly discussed in the context of English language learning and teaching, but it can occur in any situation when someone does not have a native-level command of a language, as when translating into a second language. Translation has fundamental role in human life, especially for Indonesians. It is because there is information which does not exist in Indonesian but it is presented in foreign languages, particularly in English (Choliludin, 2005:1).

Translation is not an easy work to do as it is not merely the substitution of words in one language by another language, but the transfer of meaning and sense the author wants to convey in the most natural way. It therefore, requires the training of prospective translators be done carefully in order to produce efficient translators.

Good Translation if the readers can understand target language without missing meaning. Therefore it is not easy to reach the point how to be a good translator. Students especially english students, they 
got knowledge about translation, but it was not enough to them. So students must look for other references to get more understanding about translation. Miscommunication or errors sometimes happens among people because of the grammatical aspects and lexical aspects. Grammatical is used to provide a general pattern of rule in combining words to phrases, and phrases to sentences. A good grammar will influence a good written communication, because the written text without applying the rules will invite misinterpretations for readers. Not just that, lexical aspects are needed to building sentences. It relates to the vocabulary or words in the dictionary. Lexical aspect also cannot be ignored in producing sentences.

However, most English learners do not give a significant attention to the lexical aspect. They still often make errors in their sentences. They suppose lexical is not a complicated problem, since it can be looked easily in dictionary. Lexis is the basic element which is very important to communicate, especially in written communication. An idea is impossible can be transferred without the lexis. Furthermore, Ramli proposed in his paper (2013), that lexis is considered as a very crucial thing to be mastered in humans' life because by mastering lexis, we can understand a text or communicate with others.

Review of related theories divides into some of parts, there are:

a. Overview of Translation

Translation has many definitions, which are stated by a number of theorists throughout the time. The most noticeable features of these definitions is that, some of them define it as process and a result of this process and some of them consider it as communication and skill. Meschonnic (2008: 340) states that translating is an act of language, and every act of language implies anethics of language.
The process of transferring a written text from SL to TL, conducted by a translator, or translators, in a specific sociocultural context.The written product, or TT, which results from that process and which functions in the socio-cultural context of the TL.The cognitive, linguistic, visual, cultural and ideological phenomena which are an integral part of 1 and 2 (Hatim and Munday, 2004).

This definition introduces further variables, first the 'sub-types', which include not only typically written products such as literary and technical translations, but also translation forms that have been created in recent decades, such as audio visual translation, a written product which is read in conjunction with an image on screen (cinema, television, DVD or computer game). Moreover, the reference to machine translation reveals that translation is now no longer the preserve of human translators but, in a professional context, increasingly a process and product that marries computing power and the computerized analysis of language to the human's ability to analyze sense and determine appropriate forms in the other language.

Hatim \& Munday (2004: 6) also proposes three notions on the word translation as:

1. Translation is the process of transferring a written text from source text (ST) to target text (TT), conducted by a translator, or translators, in a specific socio-cultural context.

2. The written product, or TT, which results from that process and which functions in the socio-cultural context of the TL.

3. The cognitive, linguistic, visual, cultural and ideological phenomena which are an integral part of 1 and 2.

Translation is taking a big part in communicating source language to the target language, as the speaker tells what they want, and convince the receiver to 
understanding what the speaker says. Translation is the process of transferring idea in one language to another language, while the translator is the people who translate the thing. Most translators prefer to think of their work as a profession and would like to see others treat them as professionals rather than as skilled or semiskilled workers. But to achieve this, translators need to develop an ability to stand back and reflect on what they do; that they do not just translate well because they have a 'flair' for translation, but rather because, like other professionals, they have made a conscious effort to understand various aspects of their work. It can be conclude that translation is a process of replacing message from one language into another language by finding the equivalence both in meaning and style without change the meaning of the text.

According to Kridaklasana (2008: 162) says that "Translation is the transfer of inter-cultural mandates and between languages at the grammatical and lexical level with the intention, effect, or intentions that remain as possible as possible." Translating a source language text and finding its equivalent in the target language is not easy, because translating is a fairly complicated series and the translator must maintain the original meaning of the source language so that the translation results are easily understood by the reader. In maintaining the term, translators often make changes, either grammatically or lexically according to the forms or rules that apply in the target language, so that the translation results can be expressed as naturally as possible so that they can be understood by the reader.

Now come to discussion Lexical itself. Lexical is a pattern in which words are combined to make sentences. Dinnen in Manurung (2015) wrote that lexical has grammatical forms and thus meaningful. It is not enough just to combine words but it should also be considered whether it is meaningful or not. In reaching the purpose, one should follow the system.

Sumarno (in Novia Arifatum, 2012: 2) said that translator will face variation of difficulty in meaning, such as lexical meaning, grammatical meaning, and textual meaning and socio meanings and cultural meanings. In the next discussion sessions, the researchers realized the importance of having an exact definition for the term 'lexical error'. The lexical error is according to El-Farahaty (2016: 482) it is said that lexical items of different cultures may have different functions and meanings. The lexical items can be cultural differences so they have different meanings and functions. The point from the definition of lexical errors/problem is the writer has an intended meaning encoded in the L1 and needs to find a suitable equivalent in the L2. Many lexical items consist of more than one word and have a structure of their own. Based on the literature review of lexical errors (Llach: 2005), the researchers agreed on the following definition:

"A lexical error is the wrong word use of a lexical item in a particular context in comparison with what a native speaker of similar characteristics as the L2 learner (age, educational level, professional and social status) would have produced in the same circumstances. Lexical errors can also be defined as a breach in a lexical norm of the language, which is normally observed by native speakers."

Additions, for some learners groups, lexical errors are the most frequent category of error. Next, native speakers consider the lexical errors in learners' Indonesian Learners (henceforth of IL) to be more disruptive and irritating than other types-a question we shall discuss in the context of error gravities. Finally, vocabulary carries a particularly heavy functional load, especially in early IL. There is little grammar in such IL, and the message often 
has to be inferred, mainly from the lexical terms assembled for its representation.

There is, after all, no reason to fear translation errors in the teaching situation. There is no overriding reason to insist on perfect linguistic competence or extensive text analysis before getting down to translating, since errors are going to be made, and the best way to learn is often to start making them. We all fall into error. We cannot avoid errors in every translation process because errors are usually exists during the translation process. As translators we must to overcome these errors, not to run away from these. Errors are going to be made during the process of translation, so our task as translator to get rid of the errors and try hard to present the target text as equivalent as the source text.

This study adapted lexical errors taxonomy proposed by Llach (2011) who divides lexical errors in well-ordered list based on the two major types of errors: a) Formal error is particular error in lexical error which affects the form of the word; and b) Semantic error is a particular error in lexical error which affects the meaning of the intended word. Besides, Llach (2011) divides lexical error types based on the sources of error: a) Interlingual Transfer happens because of the interference of students' mother tongue (native language); and b) Intralingual transfer happens because of the target language interference.

The following table is the distribution of lexical error taxonomy according to source and type proposed by Llach (2011):

Table 1: Category of Lexical Error

\begin{tabular}{cccc}
\hline \multirow{4}{*}{ Source } & \multicolumn{2}{c}{ Type } \\
\cline { 3 - 4 } & $\begin{array}{c}\text { Mother } \\
\text { tongue }\end{array}$ & $\begin{array}{c}\text { Formal } \\
\text { Borrowing } \\
\text { Coinage }\end{array}$ & Semantic \\
& $\begin{array}{c}\text { Calque } \\
\text { Target } \\
\text { language }\end{array}$ & $\begin{array}{c}\text { Misspelling } \\
\text { Miss election }\end{array}$ & $\begin{array}{c}\text { Semantic } \\
\text { confusion }\end{array}$ \\
\hline
\end{tabular}

Llach (2011) explains further the six main categories of lexical errors as follows: a) Llach (2011) explains further the six main categories of lexical errors as follows: In this research, borrowing refers to the error made by the students in using mother tongue without any attempt to adjust them to target language. For example: Eng. Artist. Ind. artis)

b) In this research, coinage refers to the error made by the students in using lexical item that consists of the adaptation of an L1 word to the L2 orthography or morphology that sounds like the target language. For example: (Eng. Achievement, Ind. prestasi)

c) In this research, calque refers to the error made by the students in using the words of target language by translating them literally. For example: (Eng. Have a seat please. Ind. Memiliki sebuah kursi, tolong).

d) In this research, misspelling refers to the error made by the students in using the spelling or orthography of the words in target language. For example: I am Biutiful for 'beautiful', merka for mereka in Indonesian.

e) In this research, misselection refers to the error made by the students in using the words of the target language that have sound similarity or look similarity with the words of students' mother tongue. For example: She is angry because she has not eaten yet (angry for hungry).

f) In this research, semantic confusion refers to the error made by the students in using two words of the target language which are having semantic similarity. For example: There are very shops in the city (very for "many').

Based on observation during learning process and exercising the project in the Interpreting course, Lecturer gave feedback about the students' task. The feedback can be comment, suggestion, critics, and remedy the translation. The students made some mistakes when they 
translate their project. The mistakes are in common like grammatical errors and lexical errors. occured in lexical. Then, the presences of lexical errors were some students wrongly order the word in a sentence as the result of word-by word translation. Some of students translated used translation machine like Google translate, so that it is still has an error in sentence or word.

Anyway, the subtitling in form of video and music project will be uploaded in social media such as blog and YouTube. So that, around people in the world will read it. Because of the project made by English Education Department Lancang Kuning University in form of subtitle, it will be promote the faculty and from readers will give feedback from the subtitling projects itself, also become evaluation to the next translator become a good translator.

With that reasons, the researcher is interested in finding common lexical errors in subtitling projects in translating the English text into Indonesian language.

\section{METHOD}

It is important for the researcher to use a certain kind of research method in order to achieve the objective of the research. The type of the research was descriptive quantitative. Sugiyono (2012) defines that descriptive analysis is research that describe a phenomenon, events either using quantitative and qualitative data. Addition, Arikunto (2010) states that "Penelitian deskriptif tidak dimaksudkan untuk menguji hipotesis tertentu, tetapi hanya menggambarkan "apaadanya" tentang sesuatu variable, gejala, atau keadaan. Memang, adakalanya penelitian juga ingin membuktikan dugaan, tetapi tidak terlalu lazim". In other word, descriptive quantitative have to organized and analyze the numeric data, in order to provide a view regularly, concise, and clear about a phenomenon or event.
This research was conducted on May - June 2019 at the eighth semester student of English Education Department Lancang Kuning University which is located on Jl. Yos Sudarso KM. 8, Pekanbaru. In this research the subject was 20 students who uploaded their projects in their YouTube channel. Instrument is the tool to collect the data from respondents (Sugiyono, 2015).

In this research, the instrument was documentation in form of video transcripts by uploaded students in their YouTube channel. The researcher assessed students' project based on the lexical errors category from Llach (2011). To collect the data, the researcher gathered the data from the students' final project that uploaded in the students' YouTube channel or blog sites. Then, the researcher made transcripts from it.

In analyzing the data researcher helped by two raters who is capable to analyze the students' project that is $\mathrm{Mr}$. Budianto Hamuddin, M.Esl from linguistic lecturer and Miss Refika Andriani, M.Pd from translation lecturer. The raters was given by not only the source text (English) but also the target text (Indonesian) that is considered accurate, clear, natural, and have sense of intelligibility. Here is the scoring guide in analysis the transcript:

a. Read the text from beginning to the end.

b. Give mark (encircle) to the lexical errors.

c. Analyze the wrong sentences and classifying them based on the lexical error categories.

d. Give score 1 to each lexical errors.

e. Draw the table to present the lexical errors to know many lexical errors students in subtitling project.

After that, the researcher qualified their lexical errors individually based on the Llach lexical errors taxonomy. Moreover, the researcher calculated their percentages of lexical error per indicator by using the 
formula of percentage of errors. Then the researcher drew conclusion from the process of classifying the lexical errors. The researcher used the following formula which was adapted from Healey (2010: 30) to calculate the result from data tabulation:

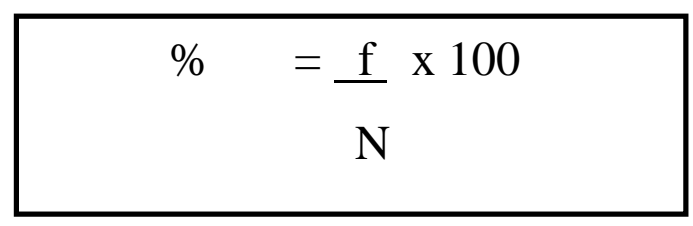

note:

$\%$ : the percentage of the students' lexical errors of each component

$\mathrm{f}$ : the number of lexical errors of each component

$\mathrm{N}$ : the total number of errors made by the students

\section{FINDINGS AND DISCUSSION}

This research was conducted based on the formulation of the research which focused on the lexical error made by students. The data of the research was gotten from 34 students' final projects of the study namely the eighth semester of English Education Department of Lancang Kuning University. The students were asked by lecturer to make subtitling by translated one video chosen randomly. They translated from English into Indonesian language. Then they uploaded in their YouTube channel. Then the researcher helped by two raters to analyze and classify the lexical errors students made. The types of Lexical errors based on the Llach (2011) theory consist of borrowing, coinage, calque, misselection, misspelling, and semantic confusion.

Steps in analyzing data first, raters read the text from the beginning to the end, gives mark (encircle) to the lexical errors found, analyze the wrong sentences and classifying then based on the lexical errors categories, give score 1 to each lexical errors. Afterward, the researcher drew the table to present the lexical errors to know many lexical errors students made to gets the descriptive data based on the two raters. The researcher also calculated the percentage of each lexical errors type made by the students. The percentage can be seen in the Table 1 below.

Table 1: The Percentage of Each Lexical Errors Type Made by the Students

\begin{tabular}{ccc}
\hline $\begin{array}{c}\text { Lexical Errors } \\
\text { Type }\end{array}$ & $\begin{array}{c}\text { Number of } \\
\text { total errors: } \\
\mathbf{1 3 6}\end{array}$ & $\mathbf{\%}$ \\
\hline Borrowing & 9 & 6.61 \\
Coinage & 7 & 5.51 \\
Calque & 28 & 20.58 \\
\hline Misselection & 28 & 20.58 \\
\hline Misspelling & 20 & 14.70 \\
$\begin{array}{c}\text { Semantic } \\
\text { confusion }\end{array}$ & 44 & 32.35 \\
\hline
\end{tabular}

Based on the Table 1 above, it can be seen that there are 9 errors of borrowing with $6.61 \%, 7$ errors of coinage with $5.51 \%, 28$ errors of calque and misselection with $20.58 \%, 20$ errors of misspelling with $14.70 \%$, and 44 errors of semantic confusion with $32.35 \%$. The percentages of students' lexical errors were converted into a pie chart. The pie chart covers the highest until the lowest rank as follows:

\section{Types of Lexical Error}

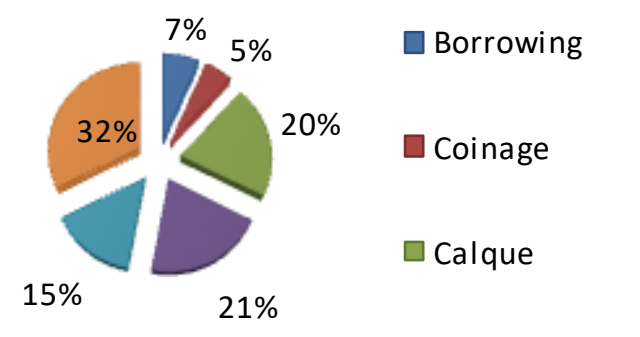

\section{Diagram 1. Frequency of Students' Lexical Errors in Subtitling Project by the First Rater}


From the Diagram 1, lexical error consist of three types, there were borrowing, coinage, dan calque.

Table 2: The Percentage of Each Lexical Errors Type Made by the Students

\begin{tabular}{ccc}
\hline $\begin{array}{c}\text { Lexical Errors } \\
\text { Type }\end{array}$ & $\begin{array}{c}\text { Number of total } \\
\text { errors: 109 }\end{array}$ & \% \\
\hline Borrowing & 8 & 7.33 \\
Coinage & 0 & 0 \\
Calque & 33 & 30.27 \\
\hline Misselection & 10 & 9.17 \\
\hline Misspelling & 18 & 16.51 \\
\hline $\begin{array}{c}\text { Semantic } \\
\text { confusion }\end{array}$ & 40 & 36.69 \\
\hline
\end{tabular}

Based on the table above, it can be seen that there are 8 errors of borrowing with $7.33 \%, 0$ errors of coinage, 33 errors of calque with $30.27 \%, 10$ errors of misselection with $9.17 \%, 18$ errors of misspelling with $16.51 \%$, and 40 errors of semantic confusion with $36.69 \%$. The percentages of students' lexical errors were converted into a pie chart. The pie chart covers the highest until the lowest rank as follows:

\section{Types of Lexical Error}

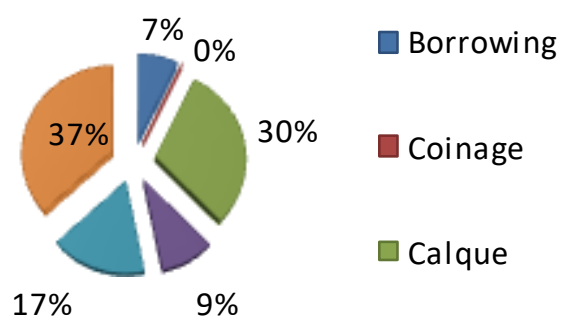

\section{Diagram 2. Frequency of Students' Lexical Errors in Subtitling Project by the second rater}

Based on the result from both of the raters analyzed, the researchers tried to draw differences. The common lexical errors made by students was semantic confusion from rater's one was 44 errors and from rater's two was 40 errors. It means that the students had enough English vocabulary but they do not know the usage of words in sentences when translate it. The rare error is coinage. It means the students have good selection in the word when translate it from source language into another language. Also, it means that students need more practice in translation because of some errors still happen.

Discussion was the main part in this research. Here, the researcher provides the result of her analysis in finding the common lexical errors in subtitling projects English into bahasa Indonesia based on the theory. The researcher only provides the data which contain the kind of errors that was explained before. The detail explanations were as follows:

As classified previously, this research was conducted at the eighth semester students of English Education Department of Faculty Education and Teachers Training Lancang Kuning University Pekanbaru. The classes were chosen due to phenomenon happened in translation especially in lexical errors. The purposes of this research were to find out the common lexical errors in subtitling project.

Some researchers in different countries found different results in investigating lexical errors made by students of different grade in various countries. For instance, Chinga (2017) found error of a coinage type because of the misconception that English word end to be shorter than Spanish ones. Then, Llach (2016) found that misselections and coinages are in the higher levels. Lastly, Shalaby (2009) discover that most of female students who were studying in preparatory year program of Tarbiah University in Al Madinah Al Munawarrah, 
Saudi Arabia produced wrong choice of suffix lexical error type in their essays.

As shown in Table 1 and Table 2, the participants committed serious lexical errors of semantic confusion, misselection, calque, misspelling, borrowing, and coinage. As far as semantic confusion is concerned, the students tended to transfer words from English when writing in Indonesian, such as "dipekerjakan kepada" (hired), "dari sejak kecil" (by a kid), "aku telah berada" (I have just arrived), "gaji yang cukup" (a good salary), "mereka adalah pemenangnya, mereka sama-sama menguntungkan, mereka ini adalah win-win (seimbang), ini ialah sebuah strategi" (it's win-win", "mereka juga ingin nenjadi bagian dari dirinya" (they wanted him to feel included), "kita putus bangkit diatas kebencian" (we let go, rise above, and move on). The students seem not to distinguish between the register choice in formal and informal writing.

Referring to the presentation and analysis of the research data above, the finding of the whole subjects (20 students) led the researcher to infer that the common lexical error of the eighth semester students of English Education Department of Faculty Education and Teachers Training Lancang Kuning University Pekanbaru in subtitling projects was semantic confusion.

Referring to the aims of descriptive quantitative design research, the findings of this research have purpose to give information for the translation lecturer about the students' common lexical errors in subtitling projects especially in addressing the lexical errors type based on the Llach (2011) such as Borrowing, Coinage, Calque, Misspelling, Misselection, and Semantic Confusion. The findings of this research are hopefully to increase the students' awareness in learning English especially in translating text mastery. Also avoid the errors especially lexical itself.
There are some strengths and weaknesses of this research. The strengths are as follows:

a. It can show description of lexical errors used in the eighth semester students subtitling projects.

b. It can show that this research different from previous related findings was the data in form of subtitling projects translated English into Indonesian. Because it is projects as subtitle that many people see in social media such as blog and YouTube. So that, around people in the world will see and read it. From it the readers can give feedback such comments, suggestions, critics, or bully. It is become evaluation to the next translator become a good translator. Because of the project made by English Education Department Lancang Kuning University in form of subtitle, it will promote the faculty.

The weaknesses of this research as follows:

a. This research used convenience or accidental sampling that could not be a representative for all the eight semester students subtitling projects.

b. When taken the data, the researcher just found some of the video projects still exist because of some reasons that have mention previously. One of the reason happened because some of students did not upload their projects after taken final exams, they delete it after got score from the lecturer.

c. This research only focused on lexical errors type by Llach (2011) such as borrowing, calque, coinage, misselection, misspelling, and semantic confusion so that has limited research.

\section{DISCUSSION}

The result research referred at research findings, there were some research findings. The researchers conducted some researches about error translation, of course the findings were different between them. 
Silalahi, et al (2018) entitled "The Analysis of Errors in Translation of Scientific Text from English to Indonesian Language" in Journal of Education, Teaching and Learning Vol. 3 No. 1. The results showed that lexical error, the majority of students made formal lexical errors in word selection and the least, the factor causing errors in translation is the majority of students do not understand the source language text and the least of which is the quality of the source language using the incorrect grammatical, the sentence is vague, the idea is not coherent and many punctuations.

The research above found that students' error in word selection, it was diffrenet with this research. This research found semantic confusion that made by students in teachers training and education faculty of Universitas Lancang Kuning the eight semester.

Chinga (2017) entitled "Lexical errors that students from juniors $1 \mathrm{~B}$ of the University of Piura Make Because of the Influence of Their Mother Tongue". She found in her result research that the majority of lexical errors Juniors $1 \mathrm{~b}$ students made, for example the error of the use of Latin nominal suffix, -ion, in all the nouns; in the other words, an overgeneralization of some suffixes. Error of a coinage types because of the misconception that English word end to be shorter than Spanish ones. On the other hand, students made only four errors with regard to calque and this is due to their level. They cannot make connections among phrases, thus they tried to it with words rather than long phrases in the majority of the example.

While the finding above found that coinage types. So it was different.

Ahmed (2017), in his research entitled "Lexical and Textual Translation by Palestinian Professional Diploma Students at the Islamic University of Gaza". $\mathrm{He}$ found that in his result showed that professional diploma students committed lexical and textual problems. Textual errors (115 errors) they are non-parallel structures (46), omissions (39), lexical repetition (16), redundant pronouns (8) and incongruent information (6). And then bilingual dictionaries have a great impact on the quality of translation resulting in many erroneous translations.

Then this finding was Textual errors or non-parallel structures.

Manurung, et al (2015) entitled "An Analysis of the Lexical Errors in Translating English Text Into Bahasa Indonesia Done by the Students of English Department University of HKBP Nomensen Medan" in The Episteme Journal of Linguistic and Literature Vol. 1. This study is about the analysis of the lexical errors in translating English text and also to find out the causes of doing the errors. In the lexical errors there are two causes of the errors, namely: Interlingual and Intralingual. In writing this the research, the writer did a descriptive method. Besides, the writer also made a test toward students of English Department of 2006/2007 academic year of Language and Art Faculty of HKBP Nommensen University. The writer asked the students to translate two English texts and find the data from the result of the translation. Finally, from the data gathered, the writer can made a conclusion that the causes of errors of the lexical errors made by the students are intralingual and interlingual causes. The causes of the errors also give effects to the result of the translation. The writer hopes that the research can be more useful to the reader in order to increase their knowledge, especially toward the students of English Department of Language and art Faculty, University of HKBP Nommensen Medan.

Then the findings above found that lexical error was caused Interlingual and Intralingual. So this research analyzed the cause lexical error that was done by English students. The researcher could concluded 
that all research findings have a differen finding. Every students have different difficulties when they translate a language, eventough translating the same object. Many students translated a target language but they were confused to know the kind of translating that they used.

Based on the findings above, the researchers could compared from some findings. It seemed different finding, this research founds semantic confusion as lexical error that was done by students.

\section{CONCLUSION}

Based on the result of research that the common lexical errors' made by students from the first rater and the second rater was semantic confusion less than $40 \%$. It meant that the students had enough English vocabulary but they do not know the usage of words in sentences when translate it. Also, it meant that students need more practice in translation because of some errors still happen. Target language as goal to get good translation. Students were expected were able to have a good intuition. Intuition is understanding'ability about something, it is very difficult to get this moment.

Referring to the finding and discussion above, it is necessary to give some suggestions as in following:

a. Students are suggested to do a lot of practice and consistent in learning in order they can get what they want from learning lexical.

b. Lecturers need to be responsible to run his/her duties.

c. For the future researcher whose extend their research related to this research, may use this research as the references and may develop this research by adding more rubric and elaboration.

\section{BIBLIOGRAPHY}

Ahmed, El Haj M. 2017.Lexical and Textual Translation Problems Encounteres by Palestinian
Professional Diploma Students at the Islamic University of Gaza.IUG Journal of Humanities Research.Vol. 25, No. 1, pp 1-13.

Arifatun, N. 2012. Kesalahan Penerjemahan Teks Bahasa Indonesia ke Bahasa Arab Melalui Google Translate (Study analysis sintaksis).Journal of Arabic Learning and Teaching.

Arikunto, S. 2010. Prosedur Penelitian. Rineka Cipta: Jakarta.

Chinga, R. 2017. Lexical Errors that Students from Junior $1 b$ of the University of Piura Make because of the Influence of their Mother Tongue. (Tesis de licenciatura en Educaciónespeciali dad en Lenguainglesa). Universidad de Piura. Facultad de Ciencias de la Educación. Piura, Perú.

Choliludin. 2005. The technique of making idiomatic translation. Kesaint Blanc: Jakarta.

Donyei, Z. 2007. Research Methods in Applied Linguistics. New York: Oxford University Press.

El-Farahaty, H. (2016).Translating Lexical Legal Terms between English and Arabic. Semiot Law.

Gunawan, F \& Rini, J. 2013. Translation Errors in English-Indonesian Humor Text Produced by Students of Basic Translation Class. Kata Kita (Journal of Literature, Language, and Teaching), 1(1), 154-163.

Hatim, B and Jeremy M. 2004.Translation: An Advanced Resource Book. London and New York: Routledge Taylor \& Francis Group.

Healey, Joseph F. 2010. The Essential of Statistics: A for Social Research. Belmont: Cengage Learning.

Kridalaksana, H. 2008. Kamus Linguistik. Gramedia: Jakarta.

Llach, M. P. A. 2015. Lexical Errors in Writing at the End of Primary and Secondary Education: Description 
and Pedagogical Implications. Porta Linguarum 23, eenero. 2011. Lexical Errors and Accuracy in Foreign Language Writing. UK: Multilingual Matters.

Manurung, EH. et al. 2015. An Analysis of The Lexical Errors in Translating English Text into Bahasa Indonesia Done by The Students of English Department University Of HKBP Nommensen Medan. The Episteme Journal of Linguistic and Literature.Vol. 1, No. 3.

Meschonnic, Henri. 2008. The Europe of translation. Journal of Translation Studies, Vol. 1, No. 1, 2008, 34_40 .ISSN 1478-1700 print/ISSN 17512921.

Munday, Jeremy. 2008. Introducing Translation Studies: Theories and Application. New York: Routledge.

Ramli. 2013. An Analysis on Students' Errors in Writing Recount Text of the Tenth Grade Student of SMAN 1 Siantan in Academic Year 2012/2013.http://jurnal.untan.ac.id/in dex.php/jpdpd/article/download/964/p df. Retrieved on January 2018.

Ross, N. K. 2005. Sample Design for Educational Survey Research. Paris. UNESCO.

Saleh, Mursid. 2011. Enam Tradisi Besar Penelitian Pendidikan Bahasa. Cet. Kedua. Semarang: Universitas Negeri Semarang Press.

Sevilla, C. G. et al. 2007. Research Methods. Rex Printing Company. Quezon City.

Shalaby, Nadia A. 2009. Analysis of Lexical Errors in Saudi College Students' Compositions. Ayn Journal of the Saudi Association of Language and Translation. Vol. 2 Issue 3.

Silalahi, Mardin. 2018. The Analysis of Errors in Translation of Scientific Text from English to Indonesian Language. Journal of Education,
Teaching and Learning.Vol.3. No. 1. Pp 23-27.

S. K., \& Given Lisa M. 2008. Convenience Sampling in the SAGE Encyclopedia of Qualitative Research Methods Thousand Oaks. CA: Sage.

Sugiyono. 2012. Metode Penelitian Kulilatif. Bandung: PT Alfabet.

2015. Metode Penelitian Kombinasi (Mix Methods). Bandung: PT Alfabet. 